\title{
Lactium: A Novel Drug for Psychocutaneous Skin Disorders
}

\author{
Amit S. Kerure ${ }^{1}$, Nitika S. Deshmukh (iD ${ }^{2,{ }^{*}}$ and Satish Udare ${ }^{3}$ \\ ${ }^{1}$ MBBS. MD. Dr Amit Kerure Skin Clinic, Navi Mumbai, India \\ ${ }^{2}$ MBBS. MD. B. J Government Medical College, Pune, India \\ ${ }^{3}$ MBBS. MD. Dr Udare Skin and Hair Clinic, Navi Mumbai, India \\ "Corresponding author: Assistant Professor, Dermatology.Ven.lep, B. J. Government Medical College, Pune, India. Email: nitikadesh15@gmail.com
}

Received 2020 December 07; Revised 2021 August 27; Accepted 2021 August 27.

Keywords: Lactium, Psychocutaneous Disorders, Milk Protein

\section{Dear editor,}

Lactium is a milk protein hydrolysate, which contains a bioactive decapeptide, known as $\alpha$ Casozepine, which binds to GABA Receptors. Gamma-aminobutyric acid (GABA) is the principal inhibitory neurotransmitter in the central nervous system (CNS). Hence, it can be used to alleviate the symptoms of pruritus or pain in psychocutaneous disorders. This article aimed at discussing the use of a novel drug called "Lactium" in dermatological (psychocutaneous) disorders.

Psychocutaneous disorders are dermatological disorders in which the symptoms of the skin disease are affected by the psychological as well as the mental state of the patient. These disorders can often be aggravated by emotional stress and/or anxiety in maximum number of cases (Table 1).

\begin{tabular}{lc}
\hline $\begin{array}{l}\text { Table 1. Represents the Proportion of Patients Regarding Disease Exacerbation Due } \\
\text { to Stress (1) }\end{array}$ \\
\hline Diseases & $\begin{array}{c}\text { Percentage of Patients, Showing Disease } \\
\text { Exacerbation Due to Stress }\end{array}$ \\
\hline Psoriasis & 54 - 60 \\
\hline Acne & 50 \\
\hline Alopecia areata & 60 \\
\hline Rosacea & 58 \\
\hline Urticaria & 16 \\
\hline Pompholyx & 17 \\
\hline Vitiligo vulgaris & 47 \\
\hline
\end{tabular}

There are few more skin diseases that are exacerbated by stress e.g., atopic dermatitis, telogen effluvium, lichen planus, psoriasis, herpes simplex infection, hyperhidrosis, etc. There can be a vicious cycle of stress-disease exacerba- tion; hence the psychological and occupational stress in the given case should be assessed. The underlying mechanisms include over-expression of corticotropin-releasing hormone (CRH), activating inflammatory and immunological processes, and action of neuropeptides (Figure 1) (2).

Usually, in such conditions, pharmacologic therapy with benzodiazepines (BDZ) and selective serotonin reuptake inhibitors (SSRIs) is used, but these have lots of side effects. In fact, $\alpha$-s1-Casein hydrolysate (Lactium) is a milk protein hydrolysate, which contains a bioactive decapeptide, called " $\alpha$ Casozepine", which binds to GABA receptors. Gamma-aminobutyric acid is the principal inhibitory neurotransmitter in the CNS (Figures 2A and B).

The pentameric GABAA receptor consists of five subunits ( $\alpha 1-6, \beta 1-3, \gamma 1-3, \delta, \varepsilon, \theta$, and $\pi)$, and the assembly of different combinations of these subunits leads to the formation of different types of GABAA receptors. Each of these subtypes has a special function and pharmacological property (4). Maximum number of GABAA receptors are composed of two $\alpha$ subunits, two $\beta$ subunits, and one $\gamma$ subunit.

Mechanism of action: Lactium binds to the GABAA receptors of the CNS. GABAA receptors, formed by a coassembly of at least 19 different subunits, have three binding sites $\omega 1, \omega 2$, and $\omega 3$ (4-6). Lactium selectively binds to $\omega 2$ binding site and results in increased membrane chloride conductance, causing an influx of chloride ions $\left(\mathrm{Cl}^{-}\right)$ and membrane hyperpolarization (Figures $2 \mathrm{~A}$ and $\mathrm{B}$ ). This leads to the reduction in neurotransmission and regulation of anxiety and stress without the sedative effects $(5,6)$.

Lactium selectively targets alpha-2 receptors that play a role in stress, anxiety, cognition, and emotions. Most of the benzodiazepines do not show any selectivity towards

Copyright (C) 2021, Journal of Skin and Stem Cell. This is an open-access article distributed under the terms of the Creative Commons Attribution-NonCommercial 4.0 International License (http://creativecommons.org/licenses/by-nc/4.0/) which permits copy and redistribute the material just in noncommercial usages, provided the original work is properly cited. 


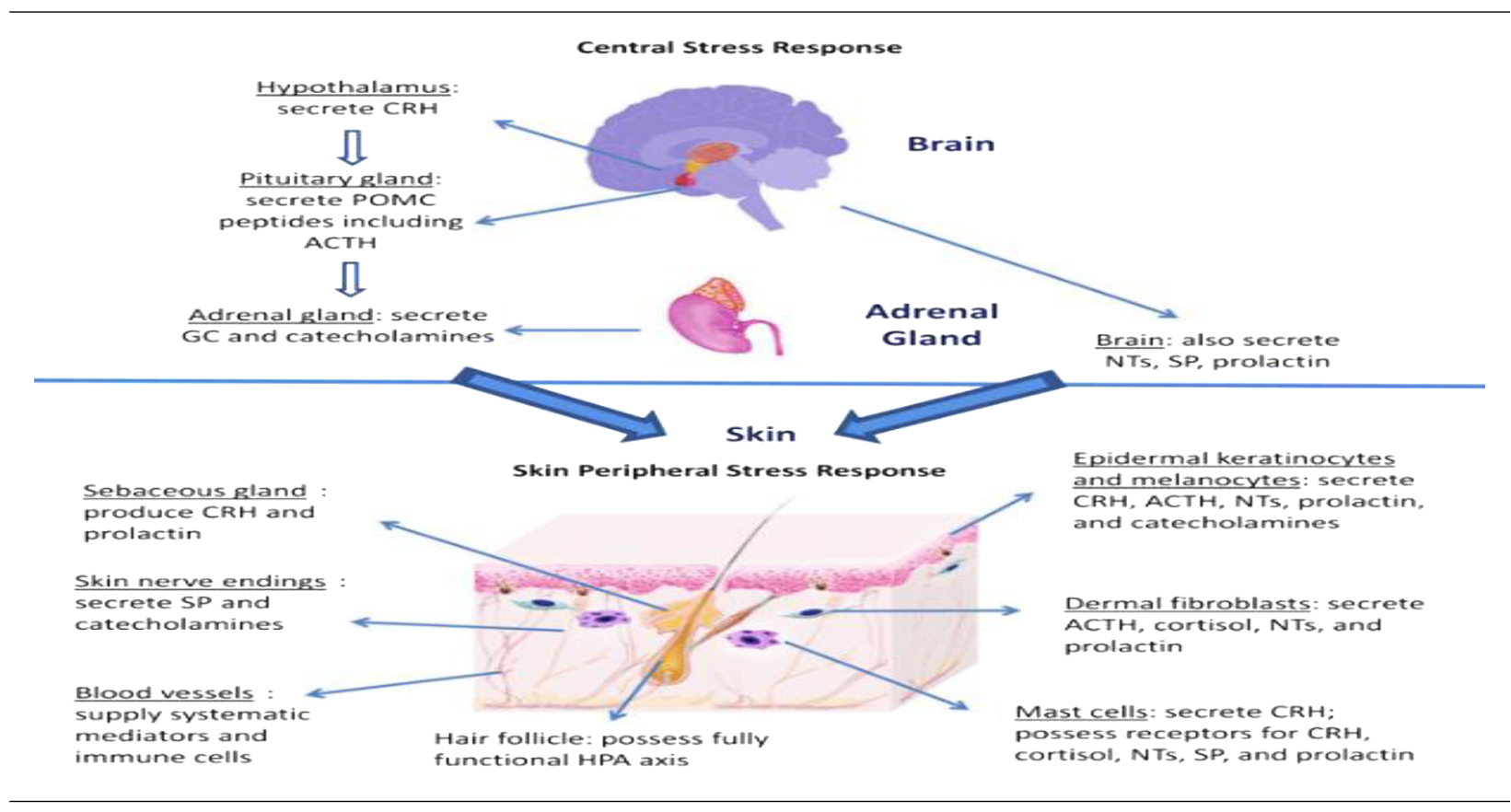

Figure 1. Schematic diagram, showing peripheral response of skin to stress (3).

alpha-1 or alpha-2 receptors. Alpha s1-Casein hydrolysate has two flexible tyrosine aromatic rings with structures that are similar to the classical benzodiazepine aromatic rings; thereby, demonstrating anxiolytic effects in addition to the blood pressure control, immune control, and anti-thrombotic effects.

Lactium has been shown to decrease serum cortisol levels, improve sleep quality and efficiency, decrease anxiety and general fatigue and reduce stress-induced symptoms related to digestion, intellectual, emotional, and social problems in several preclinical and clinical studies $(7,8)$. A complementary to chronic stress efficacy study done at Necker-Enfants Malades Hospital 46 and BIOFORTIS demonstrated the efficacy of Lactium used in higher doses (200 and $300 \mathrm{mg}$, respectively) in acute stress management and hence can be used in managing certain stress-inducing life events like school exams or special events related to private or professional life (8).

Lactium was found to be useful in alleviating symptoms associated with digestive, cardiovascular, intellectual, emotional, and social disorders for the patients (8). It is non-sedative, non-addictive anxiolytic drug that is helpful in improving disease-associated anxiety by potentiating the effect of GABA by binding to GABAA subtype of receptors, causing an influx of chloride ions, which hyperpolarizes the neurons and decreases the transmission of stress signals. However, there are no studies, so far, regard- ing its efficacy (9).

Lactium can be an adjuvant ally in the armamentarium of drugs prescribed in various stress-induced conditions like acne, psoriasis, atopic dermatitis, alopecia, urticaria, vitiligo, and many more. It is safe with no side effects or adverse events. It is a non-sedative and does not affect the cognitive ability of the patients. Managing stress and anxiety can result in better outcomes in most dermatological conditions.

\section{Footnotes}

Authors' Contribution: Concepts, Amit Kerure, Nitika Deshmukh and Satish Udare; Design, Amit Kerure and Nitika Deshmukh; Definition of intellectual content, Amit Kerure, Nitika Deshmukh and Satish Udare; Literature search, Amit Kerure and Nitika Deshmukh; Data acquisition, Amit Kerure and Nitika Deshmukh; Data analysis, Amit Kerure, Nitika Deshmukh and Satish Udare; Manuscript preparation, Amit Kerure and Nitika Deshmukh; Manuscript editing, Amit Kerure, Nitika Deshmukh and Satish Udare; Manuscript review, Amit Kerure, Nitika Deshmukh and Satish Udare; Guarantor, Amit Kerure, Nitika Deshmukh and Satish Udare.

Conflict of Interests: There was no conflict of interest. Funding/Support: There was no funding/support. 

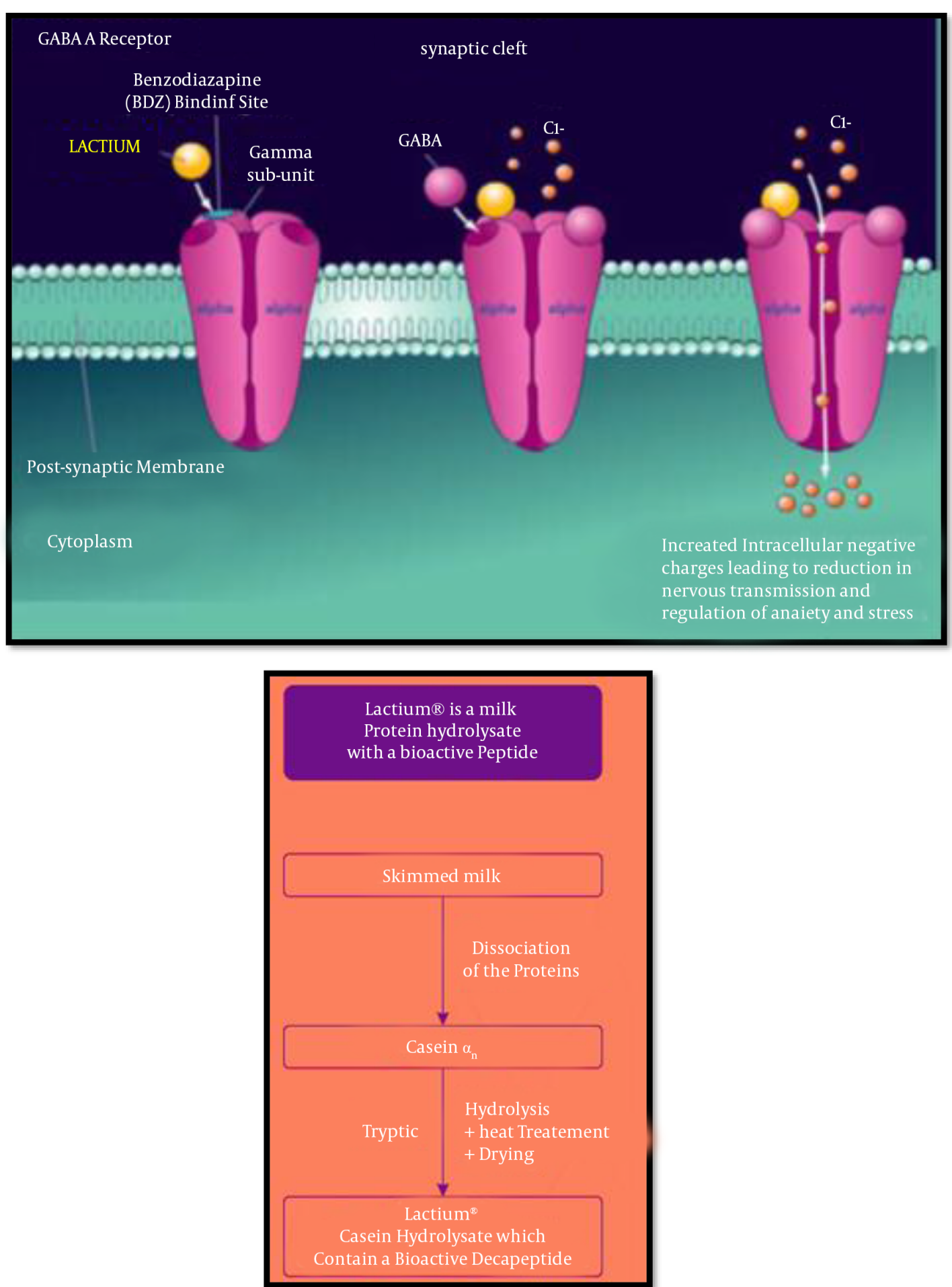

Figure 2. Schematic diagram, showing mechanism of action of Lactium. 


\section{References}

1. Yadav S, Narang T, Kumaran MS. Psychodermatology: A comprehensive review. Indian J Dermatol Venereol Leprol. 2013;79(2):176-92. doi: 10.4103/0378-6323.107632. [PubMed: 23442456].

2. Manolache L. Stress involvement as trigger factor in different skin conditions. World J dermatol. 2013;2(3):16. doi: 10.5314/wjd.v2.i3.16.

3. Chen Y, Lyga J. Brain-skin connection: Stress, inflammation and skin aging. Inflamm Allergy Drug Targets. 2014;13(3):177-90. doi: 10.2174/1871528113666140522104422. [PubMed: 24853682]. [PubMed Central: PMC4082169].

4. Nutt D. GABAA receptors: Subtypes, regional distribution, and function. J Clin Sleep Med. 2006;2(2):S7-11. [PubMed: 17557501].

5. Messaoudi M, Lalonde R, Schroeder H, Desor D. Anxiolytic-like effects and safety profile of a tryptic hydrolysate from bovine alpha s1-casein in rats. Fundam Clin Pharmacol. 2009;23(3):323-30. doi: 10.1111/j.14728206.2009.00672.x. [PubMed:19453759].
6. Kim JH, Desor D, Kim YT, Yoon WJ, Kim KS, Jun JS, et al. Efficacy of alphas1-casein hydrolysate on stress-related symptoms in women. Eur J Clin Nutr. 2007;61(4):536-41. doi: 10.1038/sj.ejcn.1602553. [PubMed: 17136040].

7. Kato M, Miyaji K, Ohtani N, Ohta M. Effects of prescription diet on dealing with stressful situations and performance of anxiety-related behaviors in privately owned anxious dogs.JVet Behav. 2012;7(1):21-6. doi: 10.1016/j.jveb.2011.05.025.

8. Messaoudi M, Lefranc-Millot C, Desor D, Demagny B, Bourdon L. Effects of a tryptic hydrolysate from bovine milk alphaS1-casein on hemodynamic responses in healthy human volunteers facing successive mental and physical stress situations. Eur J Nutr. 2005;44(2):12832. doi: 10.1007/s00394-004-0534-7. [PubMed: 15517308].

9. Shenoi SD, Soman S, Munoli R, Prabhu S. Update on pharmacotherapy in psychodermatological disorders. Indian Dermatol Online J 2020;11(3):307-18. doi: 10.4103/idoj.IDOJ_330_19. [PubMed: 32695685]. [PubMed Central: PMC7367593]. 